\title{
To the Problem of Formation of a Value Component by Active Methods of Study in the Process of Professional Training of a Student
}

\section{До проблеми формування ціннісного компонента активними методами навчання у процесі професійної підготовки студента}

\section{Nataliia Panchuk}

Ph.D. in Psychology, Assistant Professor of the Department of Psychology Education, Kamianets-Podilskyi National Ivan Ohiienko University, Kamianets-Podilskyi (Ukraine)

ORCID ID: https://orcid.org/0000-0001-9090-6073

Researcher ID: http://www.researcherid.com/rid/ABA-2631-2021

E-mail: nataliapanchuk697@gmail.com

\section{Наталія Панчук}

Кандидат психологічних наук, доцент кафедри психології освіти, Кам'янець-Подільський національний університет імені Івана Огієнка, м. Кам’янець-Подільський (Україна)

\section{Olena Secheiko}

Ph.D. in Psychology, Assistant Professor of the Department of Aviation Psychology, National Aviation University, Kyiv (Ukraine)

ORCID ID: https://orcid.org/0000-0002-7140-8252

Researcher ID: http://www.researcherid.com/rid/ABA-4233-2021

E-mail: SecheykoE@meta.ua

\section{Олена Сечейко}

Кандидат психологічних наук, доцент кафедри авіаційної психології, Національний авіаційний університет, м. Київ (Україна)

Address for correspondence, e-mail: kpnu_lab_ps@ukr.net Copyright: (C) Panchuk Nataliia, Secheiko Olena

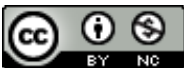
The article is licensed under CC BY-NC 4.0 International (https://creativecommons.org/licenses/by-nc/4.0/)

C Panchuk Nataliia, Secheiko Olena

DOI (article): https://doi.org/10.32626/2227-6246.2021-54.160-184 
DOI: https://doi.org/10.32626/2227-6246.2021-54

The contribution of the author: Panchuk N. $-50 \%$, Secheiko O. $-50 \%$.

Авторський внесок: Панчук Н. - 50\%, Сечейко О. $-50 \%$.

\section{ABSTRACT}

The aim of the article is the review of scientific approaches and empirical research of the problem of formation of the value component in the personality structure of future specialists, in particular, life and professional values, active teaching methods.

The following theoretical methods of the research were used to solve the tasks formulated in the article: the methods of the analysis, systematization, modelling, generalization, conversation, questionnaire, we used experimental and formative methods, methods of mathematical statistics.

The results of the research. Thus, the analysis of our results has shown that the potential of the person is manifested and acquired in the process of such activities, which gives this activity a problem-creative, exploratory nature. The article substantiates the importance of the problem of improving the quality of the professional training of future specialists in the pedagogical industry with the use of active teaching methods, specific pedagogical situations in the study of professional disciplines, in particular, practical training aimed at the formation of a personality of a specialist who would be competitive on the domestic and European labour markets.

Conclusions. The article substantiates the importance of the problem of quality improvement. To improve the organization of the educational process, the acquisition of practical skills close to the conditions of the educational process, the formation of professional and personal competencies of the future specialist in the pedagogical field, it is advisable to pay important attention to the problem of practical training through the implementation of active teaching methods in the educational process of the higher educational institutions, which is one of the main ways for acquiring the practical skills and abilities necessary for the formation of the specialist's personality, who will be competitive in the domestic and European labour market in order to be able to independently find solutions to pedagogical problems, expand professional knowledge, make original and creative decisions in conditions of the future pedagogical activity.

Key words: value orientations, professional value orientations, personal value orientations, professional training.

(C) Panchuk Nataliia, Secheiko Olena DOI (article): https://doi.org/10.32626/2227-6246.2021-54.160-184 


\section{Introduction}

The formation of the future specialist's personality in a higher educational institution sets the following main goals: mastering of professional competencies, knowledge, skills and abilities by future specialists; formation of motivational sphere and specific professional motives, attitudes, value orientations. Analysis of the structure of specialist's training indicates that the formation of the value sphere is a leading component, as value orientations contribute to success in future professional activities and ensure competitiveness in modern society. Years of study at the university fall on adolescent period. During this period, the student gets acquainted with the requirements for the chosen profession, adapts to the conditions of study at the university. Educational and professional activity, as a leading type of activity, is the main stage of life and professional path and formation of personality, its socialization. The social adaptation of students is determined by the psychological or social choice of values-goals and ways to implement them. Since the value-semantic consciousness of the personality is a set of value orientations, values, attitudes and other motives of activity and behaviour, it determines the importance of the process of its formation in the process of professional training in higher education institutions.

The researches (Бех, 2015; Боришевський, 2007; Долинська \& Максимчук, 2008; Долинська \& Стахова, 2016) on the study of the motivation of choosing a profession and students' awareness of the requirements for a modern teacher showed: the presence of a wide range of motives for choosing a profession of teacher and lack of motivation, i.e. random choice; the predominance of students' subject motives and the low level of their combination with professional motives, lack of the attitude to work at school, the decline of motives for the prestige of the teaching profession due to the social situation in the country; shifting the professional motives for choosing a teaching profession to lower ranks up to the moment of gra(C) Panchuk Nataliia, Secheiko Olena

DOI (article): https://doi.org/10.32626/2227-6246.2021-54.160-184 
DOI: https://doi.org/10.32626/2227-6246.2021-54

2021. випуск 54

duation from university. This is an evidence that the educational process of the university has little effect on the formation of professional and pedagogical orientation of the future teacher; students are superficially aware of the requirements for a modern teacher. This is confirmed by their choices mainly of those personal qualities that are not always a priority in teaching activity; the presence of negative attitudes to the activities of modern teachers and their strengthening in the process of gaining their own experience during the pedagogical practice.

The aim of the article is theoretical review of scientific approaches and empirical study of the problem of the value sphere in the personality structure of future professionals, in particular, life and professional values; analysis of the main theoretical and methodological provisions of personalityoriented education, researches of the problem of students' value sphere at the present stage of development of Ukrainian society and peculiarities of its formation.

\section{Methods of the research}

The following methods were used to form the results of the research: analysis of psychological and pedagogical literature, general scientific methods of comparison, systematization, interpretation and description of ideas and facts; questionnaire «Value orientations of the teacher».

\section{Results and their discussion}

The efficiency of the specialists' activity depends on the possession of professional competencies, values, socio-professional and personal characteristics. A reliable basis for predicting the efficiency of future professional activity is awareness of life position. Differentiation of the student's personal value system is a specific indicator of awareness. Admission to a higher education institution changes social status, social functions, roles, activities, enhances social development, includes

(c) Panchuk Nataliia, Secheiko Olena DOI (article): https://doi.org/10.32626/2227-6246.2021-54.160-184 
a person in the sphere of social relations and future profession, requires the mobilization of internal resources, natural inclinations and leads to a reassessment of values. The process of development and value-professional self-determination depends on the level and degree of social activity, self-activity and productivity of the personality oneself.

When considering the value-moral orientation, the problem of justice, which is one of the central in the ethics of professional self-determination, becomes important. Justice is considered in the following areas: it acts, firstly, as a condition of moral and ethical development of the personality, as a result of objective understanding of life realities, as a process of adequate application of rewards and punishments for the correction of social behavior; secondly, as a higher need, motive, value that motivates the personality to moral manifestations; thirdly, as a component of morality in solving problems of social content; fourthly, as an emotional experience of injustice in interpersonal and social interactions; fifthly, as a value attitude towards another person, which promotes self-realization of potentials and personal development (Клочек, 2019). It is often injustice in remuneration for the teachers' work that disorients young people in choosing a profession, forcing them to abandon basic professional ideals in favour of more profitable ones. The pedagogical orientation of the teacher's personality is determined by value orientations: on oneself; on the means of pedagogical influence; on the student, on the team, on the goals of pedagogical activity.

The basis and dynamic beginning of the system of professional and value orientations of the future teacher is the attitude to own personal and professional characteristics. In this regard, training should be carried out as an actualization of the potential professional opportunities of the personality and their development to the level of maturity. There is no need to focus on the outward flow of didactic stimuli-irritants. To manage and self-manage the process of forming a future spe(c) Panchuk Nataliia, Secheiko Olena

DOI (article): https://doi.org/10.32626/2227-6246.2021-54.160-184 
cialist, it is necessary that the student and teacher are aware of and understand the purpose of their activities. In value orientations the steady, socially-conditioned, selective relation of the person to set of material and spiritual public goods and ideals is shown. Value orientations are a component of the personality structure, which reflects the life experience accumulated by the personality in individual development and is the center of consciousness, from the point of view of which many important life issues are solved.

In order to form the value orientations of the future teacher in the process of professional training, we have developed and tested the program of the special course "Value orientations of the teacher» (Долинська \& Максимчук, 2008). The program of this special course includes the content of lectures and practical classes with the use of active teaching methods.

We built the lecture course in accordance with the developed curriculum. The content of lectures took into account the most pressing issues of psychology of values and value orientations and included consideration of the main approaches and criteria for the study of these issues in psychology; different classifications of value orientations; ways to form a system of values in adolescent period; the role of value orientations in the system of personal and professional development of future teachers; the dependence of the content of value orientations on the level of professional and pedagogical orientation of the future teacher.

We have chosen the following forms of lessons: lectures, conversations, debates, discussions of pedagogical situations, training exercises, introspection, role-playing games, etc. T. Kochubei and A. Ocheretianyi emphasize the effectiveness of the use of interactive technologies in the formation of life values of students in the course of educational disciplines (Kochubei \& Ocheretianyi, 2017; Кочубей \& Очеретяний, 2018). In foreign psychology, interactive teaching methods are widely used in working with students. The format of coaching involves

(C) Panchuk Nataliia, Secheiko Olena DOI (article): https://doi.org/10.32626/2227-6246.2021-54.160-184 
DOI: https://doi.org/10.32626/2227-6246.2021-54

2021. випУск 54

the use of interactive methods in the field of feedback-vector orientation. Feedback - in a broad sense - is a feedback in the form of a response, review, i.e. feedback on an action or event (Ruth, 2018). In particular, when a teacher gives a lecture, he or she will always wait for feedback to be found: when students will discuss the presented educational information and ask questions.

We used during lessons a form of group activity, which is determined by L.A. Onufriieva, as a cooperative form of activity during which students can share their goals (Онуфрієва, 2020). In the group form of activity, group members are interdependent, influence each other for a certain period of time, pursue a common goal, they have a sense of belonging, they are involved in the process of interactive communication (Onufriieva, 2017). The subject of each lesson determined its form.

The main tasks of the special course, set by us, are as follows: 1) expansion of students' knowledge on the problem of value sphere; 2) awareness of respondents of their own system of value orientations, identification of basic and derived values, setting priorities; 3) subjects' awareness of the coincidence of value orientations with their life goals and plans; 4) analysis of the main ways of formation of each student's own system of values, in particular, such as: primary socialization in the family; socially organized system of upbringing, education and culture, state-controlled system of ideological influence: the influence of formal and informal groups; 5) analysis of personal experience of testing the acquired values and their compliance with their own individual determination; 6) identification of coexistence in the motivational system of each student of incompatible value systems - declared and real; 7) awareness of the existing conflict of values in modern society and for each student in particular and its causality with social transformations in Ukraine; 8) identification of each subject's ideas about the meaning of life as the dominant focus of the personality type on the implementation of certain life (c) Panchuk Nataliia, Secheiko Olena

DOI (article): https://doi.org/10.32626/2227-6246.2021-54.160-184 
values; 9) semantic definiteness of the meaning of their own life and value orientations by each respondent: a) the coincidence of the subjectively conscious meaning and the real direction of the student's life; b) compliance of the chosen meaning of life, the requirements of the profession to his capabilities and individuality.

During the analysis and development of a system of ways to master pedagogical values, we relied on the theoretical and methodological provisions of the problem of personality-oriented education performed by I.D. Bekh (Bex, 2015), provisions on the psychology of creativity performed by V.O. Moliako (Моляко, 2018) and provisions of M.Y. Boryshevskyi (Боришевський, 2007), which concerned the formation of self-activity. The system of ways of mastering the values of the chosen profession, developed by us, aimed to expand the content of pedagogical values, awareness of problem situations, struggle of motives, reassessment of values and their use in specific real situations.

In developing the content of the special course, we tried to direct students to master independently the knowledge of life and professional values, acquainting them with different scientific approaches to the psychology of values. Disclosure of the debatability of modern knowledge was achieved by presenting the main approaches and criteria for the study of values, the peculiarities of the formation of value orientations of future teachers, the presence of references to original sources. All this caused the necessity for the respondents not only to master the ready-made knowledge, but also to develop their own view on a certain issue, to find additional information about it.

We based our practical training on the system-forming factor of self-knowledge as a leading component of integration of psychological knowledge into the consciousness of the future teacher, on the basis of which there is a transfer of meanings to their own actions and deeds, increased self-activity and,

(c) Panchuk Nataliia, Secheiko Olena DOI (article): https://doi.org/10.32626/2227-6246.2021-54.160-184 
DOI: https://doi.org/10.32626/2227-6246.2021-54

2021. випуск 54

as a consequence, personal growth, which also involves the expansion of value orientations. Self-knowledge and adequate self-esteem are important conditions for the expansion of value orientations, self-actualization of the personality, necessarily precede not only the processes of self-education and selfrealization, but also each individual act of goal setting. If the person has not yet figured out for himself what he aspires to in the future, what is the meaning of his life, what he needs, what he tries to be in relation to other people and to himself, what qualities he needs to develop, and which resolutely to get rid of, it indicates a lack of freedom of self-realization and holistic self-actualization of such a personality. Goal setting and realization of life goals planned on the basis of value orientations become free in case of the presence of the following conditions: formation of adequate positive self-image and awareness of coincidence of value orientations with life goals and plans, own system of value orientations, establishment of its priorities or coexistence in the motivational system of incompatible value systems, development of mental model of desired future and vision of ways and means of its achievement. Due to the activity of self-knowledge, the personality ceases to be a product of external circumstances and shows the ability to self-creation. Self-creation does not occur through a monotonous volitional effort, but grows out of the forms and content of communication with other people, and is determined by the nature of such communication.

The practical part of the special seminar is a modification of the training, as it retains all its features. The system of exercises, disputes, problem situations were selected taking into account their gradual complication, change of «I»-image. After all, at each lesson there was a new cognitive task, the result of which at the initial stage was the concretization of their own ideas about themselves and their value orientations, and at the next - the expansion of «I», reassessment of values, gaining new meanings. Methods of formation and development (C) Panchuk Nataliia, Secheiko Olena

DOI (article): https://doi.org/10.32626/2227-6246.2021-54.160-184 
of teams developed by V. Horbunova, based on the principle of axiology of the role approach (Горбунова, 2014), were important for us when using active teaching methods. After discussing the cycle of pedagogical situations, the task became more difficult to play their specific role. Certain conditions were set, and the respondents took turns playing the role of a teacher, demonstrating their own professional values by their choice. In the course of role-playing games, the subjects had a need to transform the values of the pedagogical profession from the phenomenon of «external» to the phenomenon of «internal», i.e. to become their own, personal. In the process of subsequent discussion questions, students analysed the actions and behaviour of teachers and students, realized the importance of value orientations, reliance on which allowed to solve the pedagogical task positively and successfully.

The experimental study was conducted on the basis of Kamianets-Podilskyi National Ivan Ohiienko University. The study involved 46 second-year students of the Faculty of Physical Culture and the Faculty of Ukrainian Philology and Journalism.

Exploring the value orientations, we conducted a discussion with the subjects in order to identify a collective opinion about the value orientations of the teacher. Any member of the group could speak and argue his opinion. After that, an arbitrary general list of life and professional value orientations important for the teaching profession was compiled. At the next stage, each respondent filled in his/her own sheet, indicating the values that, in his/her opinion, are the most important for the teaching profession. This ideal list was allowed to include additional value orientations that are important in the opinion of the student, but not spoken by him in the group. Then each respondent chose 10 value orientations that are important to him personally. The content of the hierarchical structure of students' value orientations was determined by the frequency of choice obtained by the value that shows the importance of a

(C) Panchuk Nataliia, Secheiko Olena DOI (article): https://doi.org/10.32626/2227-6246.2021-54.160-184 
particular value orientation. Obviously, those values that are at the top of this structure, determine the leading orientation of the individual to a particular value. This makes it possible to meaningfully describe the orientation of the personality. The values placed at the bottom of the hierarchy also characterize the orientation of the personality, as they indicate the insignificance of their goals and means for a given person. Values grouped in the middle of the hierarchy are uninformative to determine the general direction of the personality. They are characterized by the tendency to change their rank depending on the conditions of life and activities of the individual, i.e. they can be the object of educational activities in the studying process.

Based on the results of the observational experiment (Панчук, 2021), the following value orientations received the highest rank indicators: health $(84.1 \%)-1^{\text {st }}$ rank, financially secure life $(50.8 \%)-2^{\text {nd }}$ rank, the presence of good and faithful friends $(46.0 \%)-3^{\text {rd }}$ rank, knowledge (the ability to expand their horizons, education, general culture, intellectual development) (44.4\%); self-confidence (freedom from internal contradictions, doubts) $(44.4 \%)-4^{\text {th }}$ rank, happy family life (in the parental family) $(39.7 \%)-5^{\text {th }}$ rank, public recognition (respect of others, team, colleagues) (38.1) $-6^{\text {th }}$ rank, life wis$\operatorname{dom}(34.9 \%)-7^{\text {th }}$ rank, interesting work (33.3\%); future family life (separately from parents) $(33.3 \%)-8^{\text {th }}$ rank, active life $(28.6 \%)-9^{\text {th }}$ rank, good atmosphere at work $(23.8 \%)$; freedom as independence in deeds and actions (23.8\%); love for another person, sex $(23.8 \%)-10^{\text {th }}$ rank. The following value orientations received the lowest rank indicators: desire to leave the mark on earth by one's own job $(9.5 \%)-18^{\text {th }}$ rank; struggle with difficulties (overcoming difficulties) $(7.9 \%)-19^{\text {th }}$ rank; fraternity, equal opportunities for all, justice $(6.3 \%)$; communication with like-minded people $(6.3 \%)$; search for new methods and means of professional growth $(6.3 \%)-20^{\text {th }} \mathrm{rank}$, training in a pedagogical university $(3.2 \%)$; gratitude of pa(c) Panchuk Nataliia, Secheiko Olena

DOI (article): https://doi.org/10.32626/2227-6246.2021-54.160-184 
rents for pupils $(3.2 \%)-21^{\text {st }}$ rank, communication with colleagues, pupils, parents of pupils $(1.6 \%)-22^{\text {nd }}$ rank. Professional value orientations "search for new methods and means of professional growth» $(6.3 \%)$, «training in a pedagogical university» $(3.2 \%)$; "gratitude of parents for pupils» $(3.2 \%)$, «communication with colleagues, pupils, parents of pupils» $(1.6 \%)$ were chosen the least number of times. Therefore, in the second year of study in the educational process of a higher educational institution it is necessary to work on the development of professional and pedagogical orientation, as the level of this orientation is low.

According to the results of the research (Подшивайлов \& Подшивайлова, 2018: 147) of students «also on the fourth year of education the knowledge does not reach the main positions in the system of value orientations». The rank of the value "development» steadily decreases until the fourth year of education. The results of the survey (Блашкова, 2019a: 118) showed that «the following absolutely "positive» values are in priority and of the great importance for students: faithfulness $-5.3 \%$, reason $-5.1 \%$ and honesty $-5.0 \%$ " «universal values prevail at the heart of the views of modern students" (Блашкова, 2019a: 124). Professional competencies, according to O.M. Blashkova (Блашкова, 2019б: 10), «make it possible to implement the formation of humanistic and value orientation».

The vast majority of respondents (Бліхар, 2018: 119) «see the meaning of their lives in building a strong family and raising children properly» $(78.8 \%)$. Next in importance are: to improve yourself $(65.9 \%)$, to have good and reliable friends $(58.3 \%)$, to become a decent and honest person $(57.4 \%)$, to develop and «enrich yourself spiritually» (50.3\%). As we can see from the above results (Бліхар, 2018; 128-129), «students are convinced that in order to achieve success in life they need to rely on their own intelligence and abilities $(77.1 \%)$, there must have considerable faith in their own strength and inevitable

(C) Panchuk Nataliia, Secheiko Olena DOI (article): https://doi.org/10.32626/2227-6246.2021-54.160-184 
DOI: https://doi.org/10.32626/2227-6246.2021-54

2021. виПУСК 54

success (58.8\%), and, of course, professionalism, knowledge of their business and business qualities (53.3\%), and education $(53.1 \%)$ are valued».

The student's life values are interpreted (Очеретяний, 2020: 3) as «his/her main life guidelines, which determine the future professional orientation, the content of his/her educational and cognitive activities in higher educational institution and outline the style and scale of social activity».

Foreign scholars in their studies consider the life strategies of the personality as a way of organizing his/her life in the spectrum of his/her individuality and providing for his/ her own needs and aspirations. Based on life values, life strategies are stable formations that organize the integrity of life, determine the way a person lives in the future (Shealy, 2016).

A.V. Ocheretianyi defined the content and established a hierarchy of life values of American and Ukrainian students «in gradation from the greatest to the least importance for his/her life, which are formed in the following spheres of life: professional development, education, family life, social life, personal hobbies, social activity» (Очеретяний, 2020: 3).

After conducting a special course «Value orientations of the teacher» in the experimental groups, we obtained the following results of the study (see Table 1).

As it can be seen from the Table 1, among the most important value orientations for themselves, respondents singled out professional value orientations, in particular the following: profession of a teacher $(19.6 \%)$, being useful to society $(19.6 \%)$, love for children, parents $(13 \%)$, knowledge, the desire for something new $(13 \%)$, ability to communicate, mutual understanding $(8.7 \%)$. Values that are at the top of structure: health $(76.1 \%)$, financial provision $(67.4 \%)$, family $(65.2 \%)$. We explain this by the fact that in modern conditions of the spread of coronavirus disease students have realized the priority of health as the highest value for themselves, their families, humanity in general.

C Panchuk Nataliia, Secheiko Olena

DOI (article): https://doi.org/10.32626/2227-6246.2021-54.160-184 


\begin{tabular}{|c|c|c|c|c|c|c|c|c|c|c|c|c|c|c|c|c|c|c|c|}
\hline$\underset{\mathscr{C}}{\stackrel{1}{0}}$ & 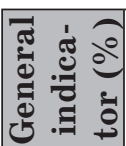 & 뭄. & $\frac{\pi}{0}$ & $\begin{array}{l}0 \\
10 \\
0\end{array}$ & $\begin{array}{l}\text { Oे } \\
\text { ஸे } \\
\text { ஸे }\end{array}$ & $\begin{array}{c}\sim \\
\stackrel{-}{N}\end{array}$ & $\left|\begin{array}{l}0 \\
0 \\
0 \\
-1\end{array}\right|$ & $\begin{array}{l}0 \\
0 \\
-1\end{array}$ & $\begin{array}{l}0 \\
\dot{0} \\
-1\end{array}$ & $\begin{array}{c}0 \\
\dot{0} \\
-1\end{array} \mid$ & $\begin{array}{c}0 \\
\dot{\infty} \\
\end{array} \mid$ & $\begin{array}{c}0 \\
\dot{0} \\
-1\end{array}$ & $\begin{array}{l}0 \\
\dot{\sim} \\
\stackrel{-}{1}\end{array}$ & $\begin{array}{l}0 \\
0 \\
0 \\
r\end{array} \mid$ & $\begin{array}{l}0 \\
\dot{r} \\
\stackrel{-1}{1}\end{array}$ & $\begin{array}{l}5 \\
\infty\end{array}$ & $\stackrel{\sim}{\infty}$ & $\left|\begin{array}{l}12 \\
0 \\
0\end{array}\right|$ & $\mid$\begin{tabular}{l|}
20 \\
0 \\
\end{tabular} \\
\hline 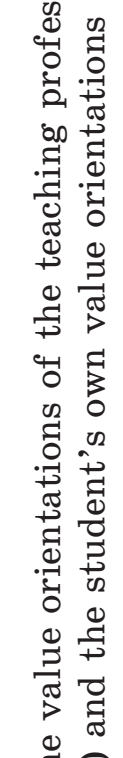 & 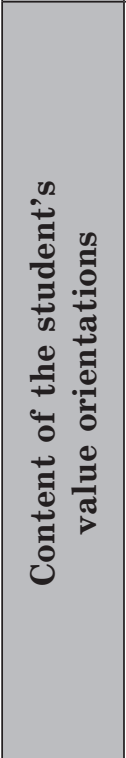 & 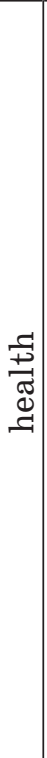 & 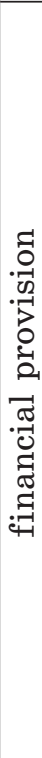 & 글 & 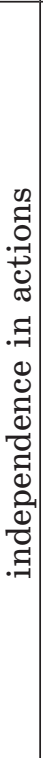 & 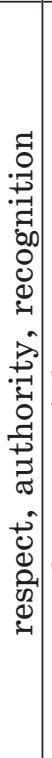 & 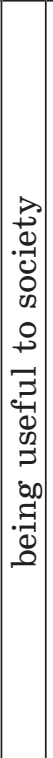 & 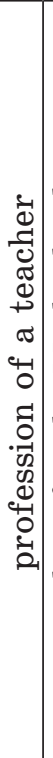 & 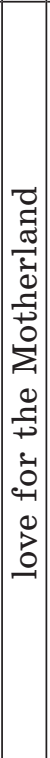 & 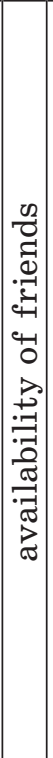 & 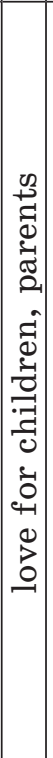 & 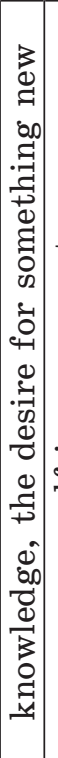 & 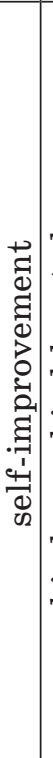 & 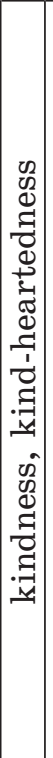 & 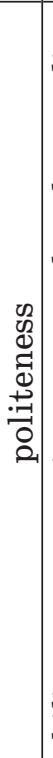 & 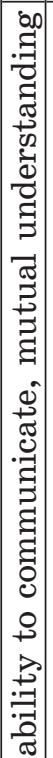 & 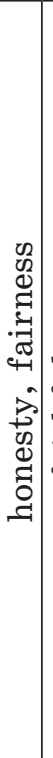 & 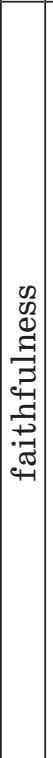 & $\stackrel{0}{0}$ \\
\hline 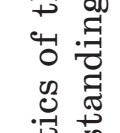 & 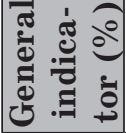 & ف․ & مُ & ִִ & $\begin{array}{l}0 \\
\dot{0} \\
\text { m }\end{array}$ & 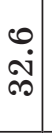 & $\begin{array}{l}0 \\
\dot{\sim} \\
\dot{m}\end{array} \mid$ & $\begin{array}{l}m \\
\infty \\
\sim \\
\sim\end{array}$ & $\begin{array}{l}\infty \\
\infty \\
\infty \\
\sim\end{array}$ & $\begin{array}{c}0 \\
\dot{m} \\
-1\end{array}$ & $\begin{array}{c}0 \\
\dot{\infty} \\
\end{array}$ & 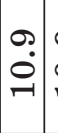 & 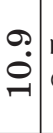 & $\stackrel{\sim}{\infty}$ & $\stackrel{\sim}{\infty}$ & $\left|\begin{array}{l}2 \\
0 \\
0\end{array}\right|$ & ف & $\left|\begin{array}{l}1 \\
0 \\
0\end{array}\right|$ & '0 \\
\hline 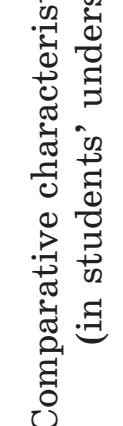 & 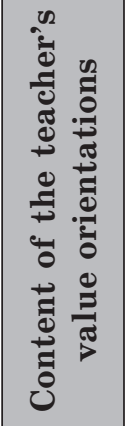 & 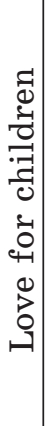 & 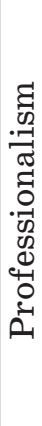 & 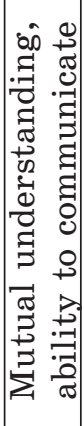 & 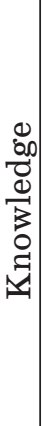 & 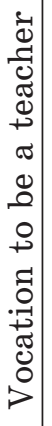 & 吾 & 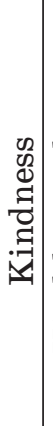 & 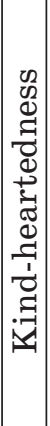 & 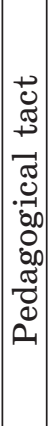 & 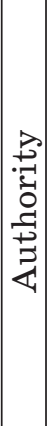 & 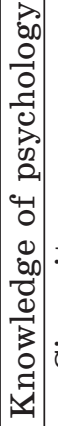 & 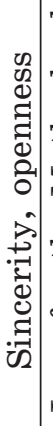 & 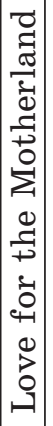 & 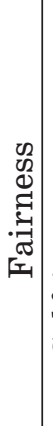 & 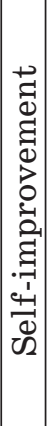 & 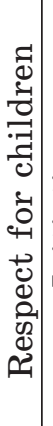 & 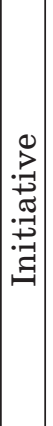 & 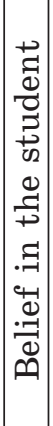 \\
\hline & $\stackrel{\dot{0}}{\dot{Z}}$ & -1 & N & $\infty$ & $\dot{\nabla}$ & 10 & 0 & $\sim$ & $\infty$ & $\sigma^{\circ}$ & $\dot{0}$ & $\stackrel{-}{\sim}$ & $\stackrel{\text { ํ) }}{-1}$ & $\dot{m}$ & $\underset{+}{+}$ & 20 & $\stackrel{0}{0}$ & $\stackrel{\sim}{\sim}$ & 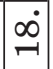 \\
\hline
\end{tabular}

(C) Panchuk Nataliia, Secheiko Olena 
DOI: https://doi.org/10.32626/2227-6246.2021-54

2021. випуск 54

The choice of financial provision is explained by the fact that education in higher education in the majority of students is paid. And mastering education is directly related to the availability of money, because in the socio-economic situation in the country - this is one of the important factors that provide the opportunity to master the future profession. That is, the availability of money acts for young people not so much as goals, but as a means of implementing the main life plans getting an interesting job.

In the conditions of distance learning, when communication becomes limited, the role of family and support of relatives grows.

According to the frequency of choosing the most priority value orientations for the teaching profession, we found the following: love for children $(76.1 \%)$; professionalism $(56.5 \%)$; mutual understanding (41.3\%); knowledge (36.9\%); vocation to be a teacher $(32.6 \%)$. Among the significant personal value orientations of students, which coincide with the main value orientations of the future teacher, we have identified the following: respect, authority, recognition $(21.7 \%)$; profession of a teacher (19.6\%); love for the Motherland (19.6\%); love for children, parents (13.0\%); knowledge, the desire for something new (13.0\%); kindness, kind-heartedness (10.9\%); self-improvement $(10.9 \%)$; ability to communicate, mutual understanding $(8.7 \%)$; honesty, fairness $(8.7 \%)$.

At this stage of development of society, national values play one of the main roles. It is important that among personal value orientations some of the respondents $(19.6 \%)$ named the following: love for the Motherland. The opinion of young men and women that society and the teacher are interrelated concepts is valuable: "The teacher is the doctor of society", «Education in the national spirit of students as builders of the future state», "Without the state the teacher will be of little value to the people». They also drew attention to the role of patriotism in life and towards the teacher.

(C) Panchuk Nataliia, Secheiko Olena

DOI (article): https://doi.org/10.32626/2227-6246.2021-54.160-184 
Thus, we can make the conclusion that students are interested in the political life of the country, care about Ukraine as a state, connect the development of the state with the future profession: they want to do something useful; to be useful to society; to be an active citizen; to find a worthy place in society. "Today, the manifestation of civic position and patriotism is one of the highest life values of Ukrainian students" (Очеретяний, 2020: 164). It is obvious that in "conditions of instability of society formation of the personality of the professional - the citizen, the patriot who clearly understands the European perspective, needs the increased attention of the state and seems as the main task of educational process of higher educational institution» (Очеретяний, 2020: 169). And although these values were chosen by a small part of the respondents (19.6\%), during the discussion they were announced and those, who were present, paid attention to them. This statement is confirmed by the fact that when summarizing the lesson, to the question of the questionnaire «Whose opinion did you like the most? What exactly?» $63.04 \%$ of respondents wrote: "On the role of the teacher in modern Ukraine», "On the role of the teacher for society», "Thoughts on working for the benefit of Ukraine». «From 2014 to 2018, students focused their own attention on national and patriotic values and the defense of the Motherland. Today, the importance of self-development is growing again. In the period from 2014 to 2018, the values of active social contacts and happy family life were more important for students. Career growth was at the heart of students' aspirations in 2014, and by 2017 it had lost its relevance. Today, students are starting to work on themselves again in terms of pursuing a high career position. ... With the change of generations in government structures in 2019, the interest of young people in a well-off life has increased" (Очеретяний, 2020: 163).

Discussions on the meaning of life as the dominant orientation of the personality for the realization of certain life (C) Panchuk Nataliia, Secheiko Olena DOI (article): https://doi.org/10.32626/2227-6246.2021-54.160-184 
DOI: https://doi.org/10.32626/2227-6246.2021-54

2021. випуск 54

value orientations were interesting and effective in expanding the value orientations of future teachers. Each student answered the questions "What is the meaning of my life?», "What is my life mission?» As a practical task, we offered a famous parable: «The wheelbarrow driver, who was carrying bricks, was asked: «What are you doing?» «Don't you see? I'm driving a wheelbarrow», he replied. The second wheelbarrow driver answered this question: «I'm earning a living for myself and my family». And the third proudly said: "I am building the Chartres Cathedral». Why, given the outward similarity of their actions, did they respond differently? Through the analysis of this parable, the researchers came to the conclusion that the fullness of human life and the degree of its self-realization and satisfaction, depending on life values, their meaning, are different.

There was a noticeable reassessment of students' value orientations when discussing the problem «The meaning of life, death and immortality». The discussion focused on philosophical and religious trends, their attempts to «reconcile» man with death, the causes of religiosity of modern man, material, historical, biological and social aspects of immortality. Respondents were aware of the essence of the immortality of their parents, teachers through the transfer of actions, experience, the quality that our students bring to the future infinity of life. We have once again addressed the problem of the value orientation of a person's life, its connection with eternal inevitable values, discussing the question «Why is the word «immortal» often synonymous with famous people?»

Thus, after passing the special course «Value orientations of the teacher», the respondents: 1 ) paid attention to the prior professional values of the teacher and correlated them with their own; 2) reflected on the place and role of the teacher in society, the opportunity to be useful to society; 3 ) connect the chosen profession with the realization of their own abilities; 4) realized the importance of the teaching profession. The ob(c) Panchuk Nataliia, Secheiko Olena

DOI (article): https://doi.org/10.32626/2227-6246.2021-54.160-184 
tained data showed that the students, in the process of conducting a special course lessons, formed an idea of the basic value orientations of the future teacher and expanded the content of professional value orientations. Lessons helped to develop a positive motivation for future professional activity. The altruistic orientation of the teacher's activity has increased. Cognitive interest in mastering the chosen profession, aimed at the realization and development of their own abilities, mastery of teaching methods, cognition, has expanded. In the behavioural aspect, the need for the implementation of value orientations related to love for the student, the ability to understand him and others, was formed. The work in the experimental group contributed to the process of formation and awareness of the participants of the special seminar of their own system of personal value orientations and their correlation with the value orientations of the future teaching profession. The emphasis shifted from professional and subject values to those related to the attitude of students to the teacher and the style of behaviour with students (mutual respect, mutual understanding, love for children), self-confidence increased.

\section{Conclusions}

Thus, the special course developed by us: promoted the acquisition of new knowledge, ways of thinking and behaving; confirmed our assumption that mastering the values of the teaching profession in the educational process is possible in case when there is identification and creation of such psychological and pedagogical conditions, under which such values acquire significant systemic nature and have a regulatory impact on independence of personality; based on the system-forming factor of self-knowledge, as a leading component of integration of psychological knowledge into the consciousness of the future teacher, there is a transfer of meanings and values to actions and deeds, increasing of self-activity and per-

(C) Panchuk Nataliia, Secheiko Olena DOI (article): https://doi.org/10.32626/2227-6246.2021-54.160-184 
sonal growth, which involves the expansion of value orientations; students' solution of game and real problem pedagogical situations creates an opportunity to include pedagogical value orientations in the context of their subjectively significant value orientations. The system of work with the values of the future teacher must become more complicated from self-awareness and change of «I-image» to the expansion of the territory of «I», reassessment of values and obtaining new meanings.

Effective forms of work are psycho-gymnastic exercises and analysis, solution of life and pedagogical situations, which would contribute to the development of positive motivation for future professional activity, to the growth of altruistic orientation of the teacher, to the expansion of cognitive interest in mastering the chosen profession, to shift the emphasis from professional and subject values to personality-oriented. Specially organized system of training lessons helps students-future teachers to realize their own life and professional guidelines and real means of achieving them. As a result, goals and values, which are important for students, are integrated into a holistic system of professional formation.

In order to improve the organization of the educational process, the acquisition of practical skills close to the conditions of the educational process, the formation of professional and personal competencies of the future specialist in the pedagogical field, it is advisable to pay important attention to the problem of practical training through the implementation of active teaching methods in the educational process of the higher educational institutions, which is one of the main pillars for acquiring practical skills and abilities necessary for the formation of the specialist's personality, who will be competitive in the domestic and European labour market in order to be able to find solutions to pedagogical problems independently, expand professional knowledge, make original and creative decisions in conditions of the future pedagogical activity.

DOI (article): https://doi.org/10.32626/2227-6246.2021-54.160-184 


\section{Literature}

Бех І.Д. Вибрані наукові праці. Виховання особистості: у 2 т. Т. 1. Чернівці : Букрек, 2015. 840 с.

Блашкова О.М. Формування гуманістичних цінностей студентів природничих спеціальностей у навчально-виховному процесі педагогічних університетів: дис. ... канд. пед. наук: 13.00.07. Київ, 2019. 238 c.

Блашкова О.М. Ключові компетентності педагога природничих дисциплін сучасної вищої школи в контексті гуманістично-ціннісного орієнтування до навколишнього середовища. Science and education a new dimension. Pedagogy and Psychology, 2019, Feb., VII (77), 188, 7-14. Budapest.

Бліхар М.П. Духовні цінності студентської молоді в сучасному українському суспільстві: дис. ... канд. соціолог. наук: 22.00.04. Львів, 2018. $271 \mathrm{c.}$.

Боришевський М.Й. Розвиток громадянської спрямованості особистості в юнацькому віці: монографія. Ін-т психологї̈ ілені Г.С. Костюка АПН України, Лабораторія психологї̈ особистості імені П.Р. Чамати. Київ : Педагогічна думка, 2007. 186 с.

Горбунова В.В. Ціннісно-рольовий підхід у теорії та практиці командотворення. Наукові студї із соціальної та політичної психологї, $2014,34,138-150$.

Долинська Л.В., Максимчук Н.П. Психологія ціннісних орієнтацій майбутнього вчителя. Кам'янець-Подільський : ФОП Сисин О.В., 2008. 124 c.

Долинська Л.В., Стахова О.О. Ціннісні орієнтації як психологічний механізм розвитку професійної самосвідомості майбутнього вчителя початкових класів. Науковий часопис НПУ імені М.П. Драгоманова: збірник наукових праць. Серія 12: Психологічні науки, 2016, 3 (48), 224-231. Київ : Вид-во НПУ ім. М.П. Драгоманова.

Клочек Л.В. Психологія соціальної справедливості у педагогічній взаємодії: автореф. дис. ... д-ра психол. наук: 19.00.07. Київ, 2019. $45 \mathrm{c.}$

Кочубей Т., Очеретяний А. Формування життевих цінностей студентів y CШA. Studia Zarzadzania i Finansyw Wyższej Szkoły Bankowej w Poznaniu, 2018, 80, 3, 43-51. Poznan.

Моляко В.О. Психологічні проблеми конструювання образу світу (загальні положення робочої концепції). Актуальні проблеми психології: Збірник наукових пращь Інституту психології імені Г.С. Костюка НАПН Украӥни. Т. ХІІ. Психологія творчості, 2018, $24,5-18$. Київ : Видавництво «Фенікс».

(C) Panchuk Nataliia, Secheiko Olena

DOI (article): https://doi.org/10.32626/2227-6246.2021-54.160-184 
DOI: https://doi.org/10.32626/2227-6246.2021-54 2021. випуск 54

Онуфрієва Л.А. Розвиток професіоналізму майбутніх фахівців соціономічних професій: соціально-психологічний вимір: монографія. Київ : Видавець Бихун В.Ю., 2020. 320 с.

Очеретяний А.В. Формування життєвих цінностей у студентів вищих навчальних закладів США та України: дис. ... д-ра філософіï: 011. Умань, 2020. 317 с.

Панчук Н.П. До питання становлення ціннісної сфери у структурі особистості майбутнього вчителя в контексті професійної підготовки. Психологічний часопис, 2021, 7, 6 (50), 49-56. Київ : Інститут психології імені Г.С. Костюка НАПН України.

Подшивайлов Ф.М., Подшивайлова Л.І. Динаміка змін основних показників мотиваційної сфери студентів-психологів (за результатами лонгітюдного дослідження). Актуальні проблели психології: Збірник наукових праць Інституту психологї імені Г.С. Костюка НАПН України. Т. ХІІ. Психологія творчості, 2018, 24, 135-152. Київ : Видавництво «Фенікс».

Kochubei, T., \& Ocheretyanyi, A. Sensitivity of students for formula of living values. Slovak international scientific journal, 2017, 1 (12), 21-24. Bratislava.

Onufriieva, L.A. The Psychology of Professional Realization of a Future Specialist's Personality: Theoretical and Methodological Aspect. Monograph. Rzeszyw : BonusLiber, 2017. $194 \mathrm{~s}$.

Ruth, D. Developing feedback for pupil learning: teaching, learning and assessment in schools. Abingdon : Oxon; New York, NY : Routledge, 2018. $155 \mathrm{~s}$.

Shealy, C.N. Making sense of beliefs and values. New York, NY : Springer Publishing, 2016. $669 \mathrm{~s}$.

\section{References}

Bekh, I.D. (2015). Vybrani naukovi pratsi [Selected research papers]. $V y$ khovannia osobystosti - Education of personality. Chernivtsi : Bukrek [in Ukrainian].

Blashkova, O.M. (2019). Formuvannia humanistychnykh tsinnostei studentiv pryrodnychykh spetsialnostei u navchalno-vykhovnomu protsesi pedahohichnykh universytetiv [The formation of humanistic values of students of science deartments in the educational process of pedagogical universities]. Candidate's thesis. Kyiv [in Ukrainian].

Blashkova, O.M. (2019). Kliuchovi kompetentnosti pedahoha pryrodnychykh dystsyplin suchasnoi vyshchoi shkoly v konteksti humanistychno-tsinnisnoho oriientuvannia do navkolyshnoho seredovyshcha [The key competencies of a teacher of science disciplines of modern

(C) Panchuk Nataliia, Secheiko Olena

DOI (article): https://doi.org/10.32626/2227-6246.2021-54.160-184 http://journals.uran.ua/index.php/2227-6246 
higher school in the context of humanistic value orientation to the environment]. Science and education a new dimension. Pedagogy and Psychology, VII (77), 188. Budapest [in Ukranian].

Blikhar, M.P. (2018). Dukhovni tsinnosti studentskoi molodi v suchasnomu ukrainskomu suspilstvi [Spiritual values of student youth in modern Ukrainian society]. Candidate's thesis. Lviv [in Ukrainian].

Boryshevskyi, M.Y. (2007) Rozvytok hromadianskoi spriamovanosti osobystosti $v$ yunatskomu vitsi [Development of civic orientation of the personality in adolescence]. Kyiv : Pedahohichna dumka [in Ukrainian].

Horbunova, V.V. (2014). Tsinnisno-roliovyi pidkhid u teorii ta praktytsi komandotvorennia [Value-role approach in the theory and practice of team building]. Naukovi studii iz sotsialnoi ta politychnoi psykholohii - Scientific studies in social and political psychology, 34, 138150 [in Ukrainian].

Dolynska, L.V., \& Maksymchuk, N.P. (2008). Psykholohiia tsinnisnykh oriientatsii maibutnioho vchytelia [Psychology of value orientations of future teacher]. Kamianets-Podilskyi : FOP Sysyn O.V. [in Ukrainian].

Dolynska, L.V., \& Stakhova, O.O. (2016) Tsinnisni oriientatsii yak psykholohichnyi mekhanizm rozvytku profesiinoi samosvidomosti maibutnoho vchytelia pochatkovykh klasiv [Value orientations as a psychological mechanism for the development of professional self-awareness of the future primary school teacher]. Naukovyi chasopys NPU imeni M.P. Drahomanova - Scientific journal of M.P. Drahomanov National Pedagogical University. Series 12: Psykhological Science, 3 (48), 224-231. Kyiv : Vyd-vo NPU imeni M.P. Drahomanova [in Ukrainian].

Klochek, L.V. (2019). Psykholohiia sotsialnoi spravedlyvosti u pedahohichnii vzaiemodii [Psychology of social justice in pedagogical interaction]. Extended abstract of Doctor's thesis. Kyiv [in Ukrainian].

Kochubei, T., \& Ocheretianyi, A. (2018). Formuvannia zhyttievykh tsinnostei studentiv u SShA [Formation of students ${ }^{6}$ vital values in the USA]. Studia Zarzadzania i Finansyw Wyższej Szkoły Bankowej w Poznaniu, 80 (3), 43-51. Poznan [in Ukrainian].

Moliako, V.O. (2018). Psykholohichni problemy konstruiuvannia obrazu svitu (zahalni polozhennia robochoi kontseptsii) [Psychological problems of constructing the image of the world (general principles of the active concept)]. Aktualni problemy psykholohii-Actual problems of psychology. Collection of research papers of H.S. Kostiuk Institute of psychology of NAES of Ukraine, 24 (XII), 5-18. Kyiv : Vydavnytstvo «Feniks» [in Ukrainian].

Onufriieva, L.A. (2020). Rozvytok profesionalizmu maibutnikh fakhivtsiv sotsionomichnykh profesii: sotsialno-psykholohichnyi vymir [The de-

(C) Panchuk Nataliia, Secheiko Olena

DOI (article): https://doi.org/10.32626/2227-6246.2021-54.160-184 
DOI: https://doi.org/10.32626/2227-6246.2021-54 2021. випУск 54

velopment of the professionalism of future specialists of socionomic professions: socio-psychological aspect]. Kyiv : Vydavets Bykhun V.Yu. [in Ukrainian].

Ocheretianyi, A.V. (2020). Formuvannia zhyttievykh tsinnostei u studentiv vyshchykh navchalnykh zakladiv SShA ta Ukrainy [Formation of life values in students of higher educational institutions in the United States and Ukraine]. Doctor's thesis. Uman [in Ukrainian].

Panchuk, N.P. (2021). Do pytannia stanovlennia tsinnisnoi sfery u strukturi osobystosti maibutnoho vchytelia v konteksti profesiinoi pidhotovky [The issue of becoming a value sphere in the structure of the personality of a future teacher in the context of professional training]. Psykholohichnyi chasopys - Psychological Journal, 7, 6 (50), 49-56. Kyiv : Instytut psykholohii imeni H.S. Kostiuka NAPN Ukrainy [in Ukrainian].

Podshyvailov, F.M., \& Podshyvailova, L.I. (2018). Dynamika zmin osnovnykh pokaznykiv motyvatsiinoi sfery studentiv-psykholohiv (za rezultatamy lonhitiudnoho doslidzhennia) [Dynamics of changes in the main indicators of the motivational sphere of psychologists (according to the results of Longitudinal Research)]. Aktualni problemy psykholohii - Actual problems of psychology. Collection of research papers of H.S. Kostiuk Institute of psychology of NAES of Ukraine, 24 (XII), 135-152. Kyiv : Vydavnytstvo «Feniks» [in Ukrainian].

Kochubei, T., \& Ocheretianyi, A. (2017). Sensitivity of students for formula of living values. Slovak international scientific journal, 1 (12), 21-24. Bratislava.

Onufriieva, L.A. (2017). The Psychology of Professional Realization of a Future Specialist's Personality: Theoretical and Methodological Aspect. Rzeszyw : BonusLiber.

Ruth, D. (2018). Developing feedback for pupil learning: teaching, learning and assessment in schools. Abingdon : Oxon; New York, NY : Routledge.

Shealy, C.N. (2016). Making sense of beliefs and values. New York, NY : Springer Publishing.

Панчук Наталія, Сечейко Олена. До проблеми формування ціннісного компонента активними методами навчання у процесі професійної підготовки студента

\section{АНОТАЦІЯ}

Мета статmі - оглянути наукові підходи й емпірично дослідити проблеми формування ціннісного компонента у структурі особистості май(C) Panchuk Nataliia, Secheiko Olena

DOI (article): https://doi.org/10.32626/2227-6246.2021-54.160-184 http://journals.uran.ua/index.php/2227-6246 
DOI: https://doi.org/10.32626/2227-6246.2021-54

2021. ВИПУСК 54

бутніх фрахівців, зокрема життєвих і професійних цінностей, активними методами навчання.

Для розв'язання поставлених у роботі завдань використано такі теоретичні методи дослідження: аналіз, систематизація, моделювання, узагальнення, бесіда, анкетування, експериментальні методи, зокрема, констатувальний і формувальний експерименти, методи математичної статистики.

Результати дослідження. Аналіз отриманих результатів показав, що потенціал особистості виявляється і набувається у процесі такої діяльності, що надає цій діяльності проблемно-творчого, пошукового характеру. Обгрунтовано важивість проблеми підвищення якості професійної підготовки майбутніх фахівців педагогічної галузі з використанням активних методів навчання, конкретних педагогічних ситуацій при вивченні фрахових дисциплін, зокрема практичної підготовки, спрямованої на формування особистості фрахівия, який був би конкурентоспроможним на вітчизняному та європейському ринках праці.

Висновки. Для покращення організації навчального процесу, набуття практичних навичок, наближених до умов освітнього прочесу, формування професійно-особистісних компетенцій у майбутнього фахівия педагогічного напряму доцільно звернути увагу на проблему практичної підготовки шляхом запровадження у навчально-виховний процес вищого освітнього закладу активних методів навчання, що є одним з основних стержнів для набуття практичних умінь і навичок, необхідних для формування особистості фахівця, конкурентоспроможного на вітчизняному та європейському ринках праці з метою можливості самостійного пошуку вирішення поставлених педагогічних завдань, розширення фахових знань, прийняття оригінальних і творчих рішень в умовах майбутньої педагогічної діяльності.

Ключові слова: ціннісні орієнтації, профресійні ціннісні орієнтації, особистісні ціннісні орієнтації, професійна підготовка.

Панчук Наталия, Сечейко Елена. К проблеме формирования ценностного компонента активными методами обучения в процессе профессиональной подготовки студента

\section{АННОТАЦИЯ}

Цель статьи - обзор научных подходов и эмпирического исследования проблемы формирования ценностного компонента в структуре лич-

(C) Panchuk Nataliia, Secheiko Olena DOI (article): https://doi.org/10.32626/2227-6246.2021-54.160-184 
ности будущих специалистов, в частности жизненных и профессиональных ценностей, активными методами обучения.

Для решения поставленных в работе задач использованы следующие теоретические методы исследования: анализ, систематизация, моделирование, обобщение, беседа, анкетирование, экспериментальные методы, в частности, констатирующий и формирующий эксперименты, методы математической статистики.

Результаты исследования. Анализ полученных результатов показал, что потенциал личности проявляется и приобретается в процессе такой деятельности, что придает этой деятельности проблемно-творческий, поисковый характер. Обоснована важность проблемы повышения качества профессиональной подготовки будущих специалистов педагогической отрасли с использованием активных методов обучения, конкретных педагогических ситуаций при изучении специальных дисциплин, в частности практической подготовки, направленной на формирование личности специалиста, который был бы конкурентоспособным на отечественном и европейском рынках труда.

Выводы. Для улучшения организации учебного процесса, приобретения практических навыков, приближенных к условиям образовательного процесса, формирования профессионально-личностных компетенций у будущего специалиста педагогического направления целесообразно обратить внимание на проблему практической подготовки через внедрение в учебно-воспитательный процесс заведения высшего образования активных методов обучения, что является одним из основных стержней для приобретения практических умений и навыков, необходимых для формирования личности специалиста, конкурентоспособного на отечественном, а также европейском рынках труда с целью возможности самостоятельного поиска решения поставленных педагогических задач, расширения профессиональных знаний, принятия оригинальных и творческих решений в условиях будущей педагогической деятельности.

Ключевые слова: ченности, ценностные ориентации, профессиональные ценностные ориентации, личностные ценностные ориентации, профессиональная подготовка.

Original manuscript received September 05, 2021 Revised manuscript accepted October 23, 2021

C Panchuk Nataliia, Secheiko Olena

DOI (article): https://doi.org/10.32626/2227-6246.2021-54.160-184 